\title{
Increased expression of C-myc proto-oncogene in biopsies of ulcerative colitis and Crohn's colitis
}

\author{
A J S Macpherson, K A Chester, L Robson, I Bjarnason, A D B Malcolm, T J Peters
}

\begin{abstract}
The steady state levels of c-myc mRNA have been measured in RNA samples extracted from colonoscopic biopsies of inflammatory bowel disease patients obtained at routine endoscopy sessions. Biopsies were immediately frozen in liquid nitrogen limiting the ischaemic time to less than 15 seconds, and can be stored for up to 96 hours before separation of RNA. Yields of RNA using biopsies were $0.137(0.041) \%$ wet wt (mean (SD), $n=68$ ), these are significantly better than those obtained from surgical material $(0.064$ $(0.063) \%$ wet wt (mean (SD), $n=21$ ) where the tissue ischaemic time was 45 minutes to one hour $\mathbf{4 0}$ minutes. Functional activity of RNA extracted was demonstrated by the ability to direct in vitro protein translation in the rabbit reticulocyte system. We have used this technique to show that there is an increased ratio of steady state c-myc proto-oncogene expression in inflamed tissue from 18 patients with left sided ulcerative colitis and five patients with segmental Crohn's colitis, compared with an uninvolved region of the colon in each case. No difference in c-myc expression was seen in biopsies at least $30 \mathrm{~cm}$ apart in 11 control patients with no macroscopic or histological abnormaities. Increased expression of c-myc in inflammatory bowel disease is consistent with the activation of this proto-oncogene during altered cell cycle control resulting from the inflammatory process.
\end{abstract}

Departments of Clinical Biochemistry and Gastroenterology, Kings College School of Medicine and Dentistry, Denmark Hill, London A J S Macpherson T J Peters

Department of Biochemistry, Charing Cross and Westminster Medical School, Fulham Palace Road, London K A Chester

L Robson

A D B Malcolm

Division of Clinical Sciences, MRC Clinical Research Centre, Harrow, Middlesex I Bjarnason

Correspondence to Dr A Macpherson Department of Medicine, King's College School of Medicine and Dentistry, Bessemer Road, Denmark Hill, London SE5 9PJ. Accepted for publication 9 September 1991
Epithelial cells of the colonic mucosa in ulcerative colitis and Crohn's colitis in relapse show increased proliferation compared with quiescent disease, or with control patients. ${ }^{1}$ This may reflect immunological damage to the colonic epithelial cells, which express HLA class II antigens in patients with active inflammatory bowel disease..$^{23}$ Although malignant change in Crohn's disease has been described, ${ }^{4}$ there is a far greater risk of colonic adenocarcinoma developing in patients with extensive longstanding ulcerative colitis. ${ }^{5}$

Proto-oncogenes were initially described as the normal cellular homologues of the transforming determinants of oncogenic retroviruses. ${ }^{6}$ These genes are normally intimately concerned with the control of cellular division and differentiation. ${ }^{6}$ There has been particular interest in the class of proto-oncogenes that code for DNA binding proteins which regulate gene transcription within the nucleus, as these may represent part of a final common pathway of cell cycle control.' The mRNAs of certain 'nuclear' protooncogenes including c-myc and c-fos increase rapidly but transiently in response to cellular stimulation by mitogens or growth factors ${ }^{89}$; these are termed early response genes.

$\mathrm{C}-m y c$ was originally described as the cellular homologue of the oncogene in the avian myelocytomatosis virus (v-myc). ${ }^{6}$ It codes for a nuclear protein $^{10}$ that dimerises and binds to DNA ${ }^{11}$ through an amphipathic helix structure, ${ }^{12}$ and it normally acts to regulate gene transcription..$^{81011}$ $\mathrm{C}-m y c$ is one of the early response genes, and the mRNA and protein product are increased in cultured cells exposed to mitogens. ${ }^{89}$ In tumours, myc can be activated by translocation in lymphomas or amplification in neuroblastomas. ${ }^{131+}$ Increased steady state levels of $c-m y c$ mRNA have been detected in colorectal adenocarcinomas with differing frequencies, ${ }^{15-17}$ although translocation or amplification is very rarely seen. ${ }^{18}$

Monoclonal antibodies raised to synthetic peptides from hydrophilic parts of the derived protein sequence of Myc have been used to detect an 62000 molecular weight gene product by Western blotting. ${ }^{18} 19$ These antibodies have been used for immunohistochemistry in which increased Myc protein has been shown in adenomatous polyps, ulcerative colitis and Crohn's disease. ${ }^{20-23} \mathrm{~A}$ major limitation of this technique has been the detection of the protein in the epithelial cell cytoplasm as well as the nucleus, so the significance of the results is uncertain. ${ }^{2+}$

In this paper we have characterised RNA extracted from colonoscopic biopsies and compared the yields obtained with RNA prepared from surgical material where there is inevitably a longer ischaemic time. Using RNA from colonoscopic biopsies we have directly measured the steady state levels of c-myc mRNA in the colonic mucosa of patients with inflammatory bowel disease.

\section{Methods}

\section{COLONOSCOPIC BIOPSIES}

Biopsies were taken from 34 patients at colonoscopy at Northwick Park and King's College Hospitals using an Olympus CF10L endoscope and spiked biopsy forceps. Samples were taken from macroscopically active and inactive regions in patients with known or suspected inflammatory bowel disease. For each set, two parallel biopsies were taken from the same region and fixed in formalin for histopathology; this allowed confirmation of the diagnosis and assessment of disease activity. In no case was epithelial dysplasia observed. Eighteen patients had left sided ulcerative colitis (10 male: eight female; mean age 46 years; range $22-80$ ) and five patients had segmental Crohn's colitis ( 2 male: three female; mean age 41 years; range 30-68). Colonoscopic 
biopsies were also taken from different regions in 11 control patients (five male: six female; mean age 42 years; range 22-69) where the examination had revealed no abnormality, and in whom a final diagnosis of irritable bowel syndrome was made. These were immediately frozen and stored in liquid nitrogen. The time lapse from taking the biopsy to freezing was never more than 15 seconds.

All patients gave informed consent. These studies were approved by the Harrow Health Authority and King's College Hospital ethical committees.

\section{RNA PREPARATION}

Total RNA was prepared by an adaptation of the method of Chirgwin et al. ${ }^{25}$ Throughout the protocol, precautions were taken to eliminate exogenous ribonuclease during handling of the specimens and from the apparatus and reagents. ${ }^{26}$ The biopsy samples or specimens of normal colonic mucosa obtained at surgery ( 21 patients 12 male: nine female; mean age 68 years; range 49-84) were removed from liquid nitrogen, and homogenised with a Polytron in $3 \mathrm{ml}$ of $5 \cdot 2 \mathrm{M}$ guanidium isothiocyanate, $0.5 \%(\mathrm{w} / \mathrm{v})$ sodium lauryl sarcosine, $100 \mathrm{mM}$-2-mercaptoethanol, $25 \mathrm{mM}$ sodium citrate $(\mathrm{pH} \mathrm{7.0})$ Caesium chloride $(1.25 \mathrm{~g})$ was dissolved in each homogenate, and this was layered over a cushion of $1 \mathrm{ml} 5.7 \mathrm{M}$ caesium chloride in $4.4 \mathrm{ml}$ polycarbonate tubes. Centrifugation was carried out at $33000 \mathrm{rpm}$ for 18 hours in a Sorvall $6 \mathrm{TD} 65 \mathrm{~B}$ centifuge at $20^{\circ} \mathrm{C}$. After this, the supernatant was removed and the tubes were inverted. The pellet was resuspended in $0.36 \mathrm{ml} 0.2 \mathrm{M}$ sodium chloride, and incubated with $1 \mathrm{ml}$ ethanol overnight at $-20^{\circ} \mathrm{C}$. The RNA was precipitated by centrifugation in an Eppendorf microfuge at $4^{\circ} \mathrm{C}$ for 15 minutes, and resuspended in $70 \%$ ethanol for storage at $-80^{\circ} \mathrm{C}$.

\section{A B C D E F G H I J K L M}

Figure 1: Glyoxal gel electrophoresis of total RNA preparations extracted from colonoscopic biopsies or colonic mucosa excised at surgery. $5 \mu \mathrm{g} R N A$ was glyoxalated ${ }^{2 \times}$ and separated by $1 \cdot 2 \%$ agarose gel electrophoresis. Arrows indicate the positons of the $18 S$ and $28 S$ ribosomal RNA bands.

Tracks A-F RNA preparations from surgical specimens, tracks $G-L$. RNA preparations from colonoscopic biopsies. In tracks $G-L$ high molecular weight mRNA can be seen above the upper (28S) ribosomal $R N A$ band. Track $M$

bacteriophage lambda Hind III markers.

\section{SLOT BLOT HYBRIDISATION}

RNA $(1 \mu \mathrm{g}$ or $4 \mu \mathrm{g})$ was denatured by heating to $65^{\circ} \mathrm{C}$ for 10 minutes in $200 \mu \mathrm{l} 7 \cdot 5 \%$ formaldehyde and 6XSSC (saline sodium citrate $)^{26}$. These samples were applied to nitrocellulose filters using a Schleicher \& Schuell manifold. The filters were dried at room temperature and baked at $80^{\circ} \mathrm{C}$ for two hours before prehybridisation for two to six hours at $65^{\circ} \mathrm{C}$ in 6XSSC, 5XDenhardt's, ${ }^{26} 0 \cdot 1 \%$ sodium dodecyl sulphate (SDS) and $100 \mu \mathrm{g} / \mathrm{ml}$ denatured salmon sperm DNA. Hybridisation was carried out at $65^{\circ} \mathrm{C}$ for 12 hours in prehybridisation buffer with a ${ }^{32} \mathrm{P}$-labelled random hexamer primed exon 2 c-myc fragment or chick brain $\beta$ actin fragment. ${ }^{2627}$ Unbound radioactivity was removed by two 15 minute washes in 2XSSC, $0 \cdot 1 \%$-SDS, the first at room temperature and the second at $65^{\circ} \mathrm{C}$. A final 15 minute wash in $0 \cdot 2 \mathrm{XSSC}, 0 \cdot 1 \%$-SDS was carried out at $65^{\circ} \mathrm{C}$. Hybridisation was detected by autoradiography using Hyperfilm $\mathrm{MP}$ (Amersham) at $-70^{\circ} \mathrm{C}$. The bands were quantified by scanning densitometry on a Joyce-Loebl Chromoscan.

\section{NORTHERN HYBRIDISATION}

Samples of RNA $(15 \mu \mathrm{g})$ were denatured by treatment with glyoxal and dimethylsulphoxide as described by McMaster \& Carmichael..$^{28}$ These were loaded in $50 \%$-glycerol, $10 \mathrm{mM}$ sodium phosphate $(\mathrm{pH} 7 \cdot 0), 0.4 \%$ bromophenol blue onto a $1 \cdot 2 \%$ agarose gel in $10 \mathrm{mM}$ sodium phosphate (pH 7.0) buffer. RNA ladder markers were loaded in a lane on the edge of the gel. The gel was run at $3 \mathrm{~V} / \mathrm{cm}$ in a submarine system with recirculation of the buffer from the cathode to the anode with a peristaltic pump. At the end of electrophoresis the RNA samples and markers were transferred to Hybond-N (Amersham) by capillary blotting. ${ }^{26}$ The tracks containing the RNA ladder markers were excised from the filter and stained with methylene blue. The remainder of the filter was dried, baked and hybridised as described above.

\section{CDNA PREPARATION}

Total RNA $(15 \mu \mathrm{g})$ from term placenta was redissolved in $20 \mu \mathrm{l}$ water and heated to $65^{\circ} \mathrm{C}$ for 10 minutes and cooled on ice. This was incubated for 1.5 hours at $37^{\circ} \mathrm{C}$ with $0.15 \mathrm{M}$ TrisHCl (pH 8.3), $0 \cdot 18 \mathrm{M}$ sodium chloride, $12 \mathrm{mM}$ magnesium acetate, $20 \mathrm{mM}$ DTT, $150 \mu \mathrm{g} / \mathrm{ml}$ oligodT, 30 units RNasin, $1 \mathrm{mM}$ dATP, $1 \mathrm{mM}$ dGTP, $1 \mathrm{mM}$ dTTP, $50 \mu \mathrm{Ci}(3000 \mathrm{mM} / \mathrm{Ci})$ $\left[\alpha^{32} \mathrm{P}-\mathrm{dCTP}\right]$ and 10 units AMV reverse transcriptase. Remaining RNA was hydrolysed at the end of this reaction with $75 \mathrm{mM}$ sodium hydroxide, $20 \mathrm{mM}$-EDTA at $65^{\circ} \mathrm{C}$ for one hour. The mixture was subsequently neutralised and unincorporated radioactivity was separated by Sephadex G50 gel filtration.

\section{IN VITRO TRANSLATION}

In vitro protein translation was carried out in the presence of $\left[{ }^{35} \mathrm{~S}\right]$ methionine using the rabbit reticulocyte lysate system..$^{26}{ }^{24}$ Anaemic rabbi blood was collected and treated with micrococcal 


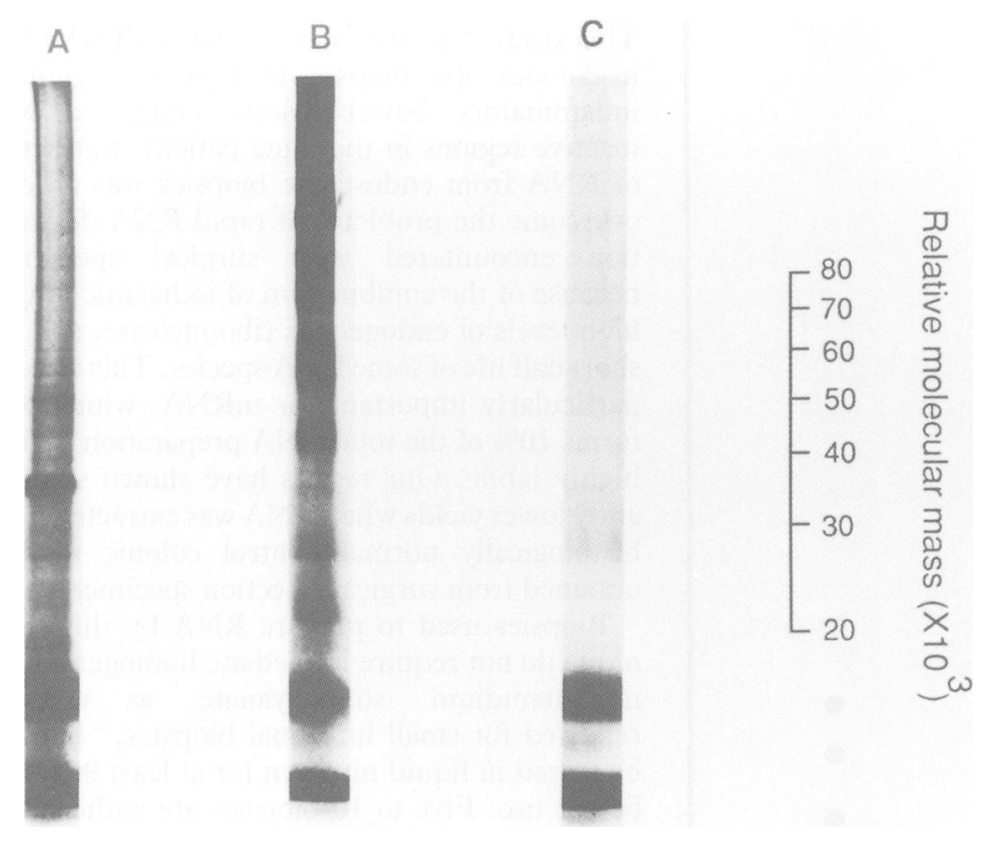

Figure 2: In vitro protein translation directed by RNA preparations extracted from colonoscopic biopsies. $\left[{ }^{35} S\right]$ Methionine was incorporated using the rabbit reticulocyte system. ${ }^{29}$ Proteins were separated by SDS/polyacrylamide (12.5\%)-gel electrophoresis; positions of molecular weight markers (on the stained gel) are indicated. Autoradiography was carried out after drying the gel. Track A protein translation directed by RNA preparation from colonoscopic biopsies; track $B$, protein translation directed by 5 ng tobacco mosaic virus $R N A$; track $C$, no $R N A$ added to rabbit reticulocyte system.

\section{A $B \quad$ C}

nuclease in the presence of haemin and calcium chloride; digestion of endogenous mRNA was terminated by the addition of EGTA. ${ }^{28}$ Samples of RNA $(10 \mu \mathrm{g})$ were translated with $10 \mu \mathrm{l}$ reticulocyte lysate in a total volume of $25 \mu \mathrm{l}$ containing $0.5 \mathrm{mM}$ spermidine, $8 \mathrm{mM}$ creatine phosphate, $25 \mu M$ each amino acid except methionine, $2 \mathrm{mM}$ dithiothreitol, $20 \mathrm{mM}$ HEPES (pH 7.4), $70 \mathrm{mM}-\mathrm{KCl}, 0.65 \mathrm{mM}$ magnesium acetate and $80 \mu \mathrm{Ci}(1200 \mathrm{Ci} / \mathrm{mmol})$ $\left[{ }^{35} \mathrm{~S}\right]$ methionine. This mixture was incubated at $30^{\circ} \mathrm{C}$ for 1.5 hours, when a $5 \mu \mathrm{l}$ aliquot was analysed by SDS/polyacrylamide (12.5\%) gel electrophoresis. ${ }^{30}$ The gel was stained with Coomassie blue and destained with $7 \%$ methanol before drying and autoradiography. Control incubations were carried out with the addition of $20 \mathrm{ng}$ tobacco mosaic virus RNA, and with no added RNA.

\section{STATISTICAL ANALYSIS}

Statistical analysis was carried out using the Student's $t$ test and the Wilcoxon's signed rank test. ${ }^{31}$

Figure 3: Northern hybridisation of $R N A$ preparations from colonoscopic biopsies with ${ }^{32} \mathrm{P}$ labelled exon $2 c$ myc probe. Track $A$, ulcerative colitis; track $B$ ulcerative colitis; track $C$, normal mucosa. Position of $2 \cdot 2 \mathrm{~kb}$ band calculated from RNA ladder markers which were excised from the gel and stained separately before Northern blotting.

\section{Results}

Colonoscopic biopsies were taken from 18 patients with mild or moderately active left sided ulcerative colitis, and from five patients with segmental Crohn's colitis. In each case control biopsies were taken from a macroscopically normal region in the same patient, two biopsies from active and inactive regions were processed for histopathological confirmation of the diagnosis. In 11 control patients, biopsies were taken at least $30 \mathrm{~cm}$ apart; in these cases separate biopsies showed no histological abnormality.

\section{RNA PREPARATION AND CHARACTERISATION}

Total RNA was prepared from each set of five to 10 biopsies by caesium chloride density gradient centrifugation after homogenisation in guanidium isothiocyanate buffer to denature endogenous ribonuclease. An absorption spectrum showed a single peak at $\mathrm{OD}_{260} \mathrm{~nm}$, and the $\mathrm{OD}_{260} / \mathrm{OD}_{280}$ ratios were $1 \cdot 81(0 \cdot 16)(\mathrm{SD} ; \mathrm{n}=68)$ with yields of $0 \cdot 137(0.041) \%$ from $14-66 \mathrm{mg}$ wet weight of tissue. RNA was also prepared by this method from normal colonic mucosa resected at surgery; this showed yields of $0.064(0.063) \%$ $(\mathrm{SD} ; \mathrm{n}=21)$; these are significantly lower than the yields obtained from the colonoscopic biopsy specimens (Student's unpaired $t$ test: $\mathrm{p}<0.01$ ). RNA extracted from both biopsies and surgical samples showed two distinct bands corresponding to $28 \mathrm{~S}$ and $18 \mathrm{~S}$ ribosomal RNA after separation by glyoxal agarose gel electrophoresis (Fig 1), this also shows that high molecular weight mRNA (above the $28 \mathrm{~S}$ ribosomal RNA) is seen in samples derived from biopsies but not surgical material although an identical amount of RNA $(5 \mu \mathrm{g})$ was loaded to each track. Differences in yield may therefore include losses in the labile mRNA fraction of total RNA, because the ischaemic time during surgery varied from 45 minutes to one hour 45 minutes.

Biopsy preparations of RNA were successfully used to direct in vitro protein translation in the rabbit reticulocyte system (Fig 2) where endogenous RNA is destroyed by pretreatment with micrococcal nuclease; the major translation product was of molecular weight 34000 with distinct protein bands up to 68000 . Control incubation of this system without the addition of RNA showed no incorporation of $\left[{ }^{35} \mathrm{~S}\right] \mathrm{methionine}$ into protein, although unincorporated label was seen in two bands at the gel front (Fig 2). The translation of distinct proteins from the RNA that has been isolated from biopsies shows that functionally active mRNA is obtained. No difference in the absorption spectrum or improvement in yield was obtained if the biopsies were immediately homogenised in guanidium isothiocyanate rather than being frozen in liquid nitrogen for 12-96 hours before further processing.

\section{EXPRESSION OF C-MYC PROTO-ONCOGENE}

To confirm that there was a c-myc mRNA transcript of the expected size in the colonic biopsy RNA preparations, Northern blots were hybridised with an exon $2 \mathrm{c}-m y c$ probe. A band of $2 \cdot 2 \mathrm{~kb}$ was seen in RNA extracted from active ulcerative colitis, and (faintly) in normal tissue
(Fig 3).

To quantify c-myc proto-oncogene expression in the small RNA samples available, slot blot hybridisation was used. This had the advantage that $4 \mu \mathrm{g}$ RNA samples were sufficient; these were applied to a nitrocellulose filter using a manifold apparatus and hybridised with the c-myc probe. The signals obtained by autoradiography of the filter were quantified by scanning 


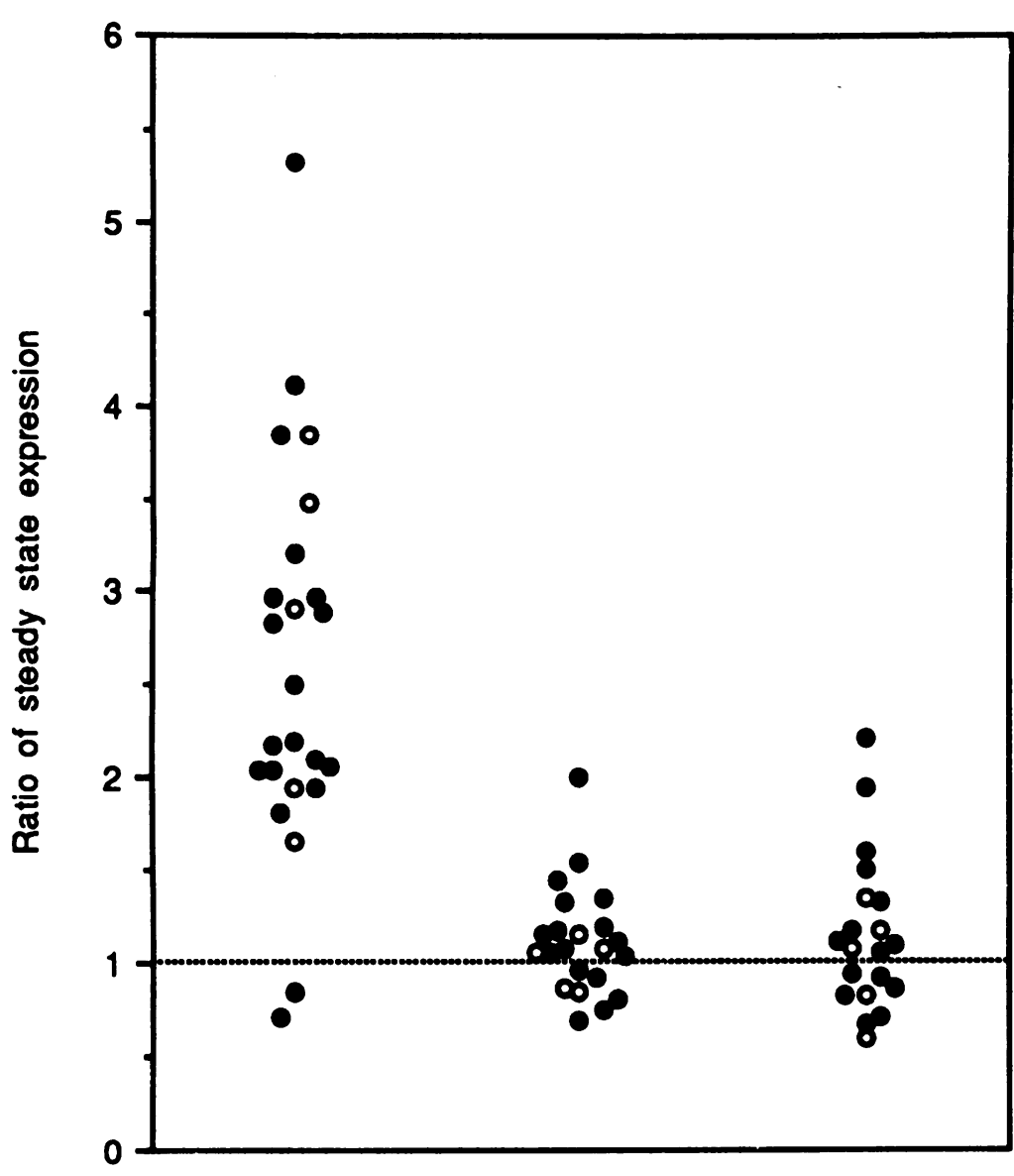

C-myc Total mRNA Actin mRNA

Figure 4: Ratio of expression of c-myc in left sided ulcerative colitis (closed symbols) and segmental Crohn's colitis (open symbols) compared with control mucosa taken from an inactive region of the colon in the same patient. RNA samples $(4 \mu \mathrm{g})$ were applied to a nitrocellulose filter using a Schleicher and Schuell manifold. The filter was hybridised with an exon $2^{32} P$ labelled c-myc probe. Replica filters were hybridised with $\left[^{32} P\right] c D N A$ to quantify $m R N A$, and $\Gamma^{32} P J \beta$-actin probe. In three ulcerative colitis patients the RNA yields were insufficient to permit measurement of $\beta$-actin mRNA. After hybridisation the filters were washed to a final stringency of $0 \cdot 2 X S S C, 0 \cdot 1 \%-S D S$ and autoradiographed. Bands were quantified by scanning on a Foyce-Loebl Chromoscan. Each point is the mean of duplicate measurements.

densitometry. Results are shown in Figure 4. There is an increased ratio of $c-m y c$ expression in (left sided) ulcerative colitis compared with normal colonic mucosa taken from the same patient. Parallel replica filters were used to probe with oligo-dT primed cDNA to measure total mRNA applied to each slot; these showed no differences between the colitic and control biopsies (Fig 4). Similarly, there were no differences in the expression of the constitutive gene $\beta$-actin (Fig 4). There was also an increased ratio of c-myc expression in segmental Crohn's colitis compared with control colonic mucosa from the same patient, and there were similarly no differences in the amount of overall mRNA or $\beta$-actin expression (Fig 4). The increased steady state ratio of c-myc expression compared with total mRNA levels is highly significant $(\mathrm{p}<0.01)$ by the Wilcoxon's signed rank test for both ulcerative and Crohn's colitis. These differences do not reflect alterations in c-myc expression at different positions of the colon, because in 11 patients with no macroscopic or histological abnormality there was no difference in c-myc expression in biopsies taken at least $30 \mathrm{~cm}$ apart (Fig 5).

\section{Discussion}

This study describes raised c-myc mRNA levels in colonoscopic biopsies from active regions of inflammatory bowel disease compared with inactive regions in the same patient. Extraction of RNA from endoscopic biopsies was used to overcome the problems of rapid RNA degradation encountered with surgical specimens because of the combination of ischaemic injury, high levels of endogenous ribonuclease, and the short half life of some RNA species. This effect is particularly important for mRNA, which only forms $10 \%$ of the total RNA preparation ${ }^{32}$ but is highly labile. Our results have shown significantly lower yields when RNA was extracted from histologically normal control colonic mucosa obtained from surgical resection specimens.

Biopsies used to prepare RNA by this technique do not require immediate homogenisation in guanidium isothiocyanate, as recently reported for small intestinal biopsies, ${ }^{33}$ but can be stored in liquid nitrogen for at least 96 hours before use. Five to 10 biopsies are sufficient to yield 8-76 $\mu \mathrm{g}$ total RNA. Such RNA preparations are undegraded on glyoxal gel electrophoresis, and can successfully direct in vitro protein translation. We have recently prepared a cDNA library in bacteriophage lambda ZAP II from the polyA+ fraction of RNA extracted from colonic biopsies in two healthy adult volunteers. This library has $1.3 \times 10^{6}$ recombinants with insert size $0 \cdot 8-4.0 \mathrm{~kb}$. The convenience of this procedure in which biopsies can be immediately frozen without the necessity for further processing during routine endoscopy sessions, and the high yields of functional mRNA obtained, suggests that this technique may be convenient to study gene expression in other gastrointestinal disorders.

C-myc belongs to a group of proto-oncogenes which normally act to regulate gene transcription, and they appear to be important in the control of cell division and differentiation. Oncogenes have widespread interest because raised expression or mutant forms are associated with transformation in the genesis of malignant tumours. C-myc has received special attention in man because of translocations that occur in lymphomas and increased expression in colorectal adenocarcinomas.

We have shown that the steady state level of c-myc mRNA expression is increased in colonic biopsies from involved areas of ulcerative colitis, and segmental Crohn's colitis. As c-myc shows a transient increase when cultured cells are treated with mitogens or growth factors, ${ }^{x}$ our technique of obtaining RNA without a significant tissue ischaemic time was particularly valuable. C-myc expression was assessed by slot blot hybridisation owing to the small amounts of RNA obtained from some cases, Northern hybridisation has shown that the expected $2 \cdot 2 \mathrm{~kb}$ c-myc transcript is detected under these experimental conditions. Control experiments have shown that neither the total mRNA nor the ratio of $\beta$ actin mRNA expression was altered under these conditions. These results show that there is either increased transcription of the c-myc gene, or reduced degradation of the mRNA in active inflammatory bowel disease. Similar increases in 


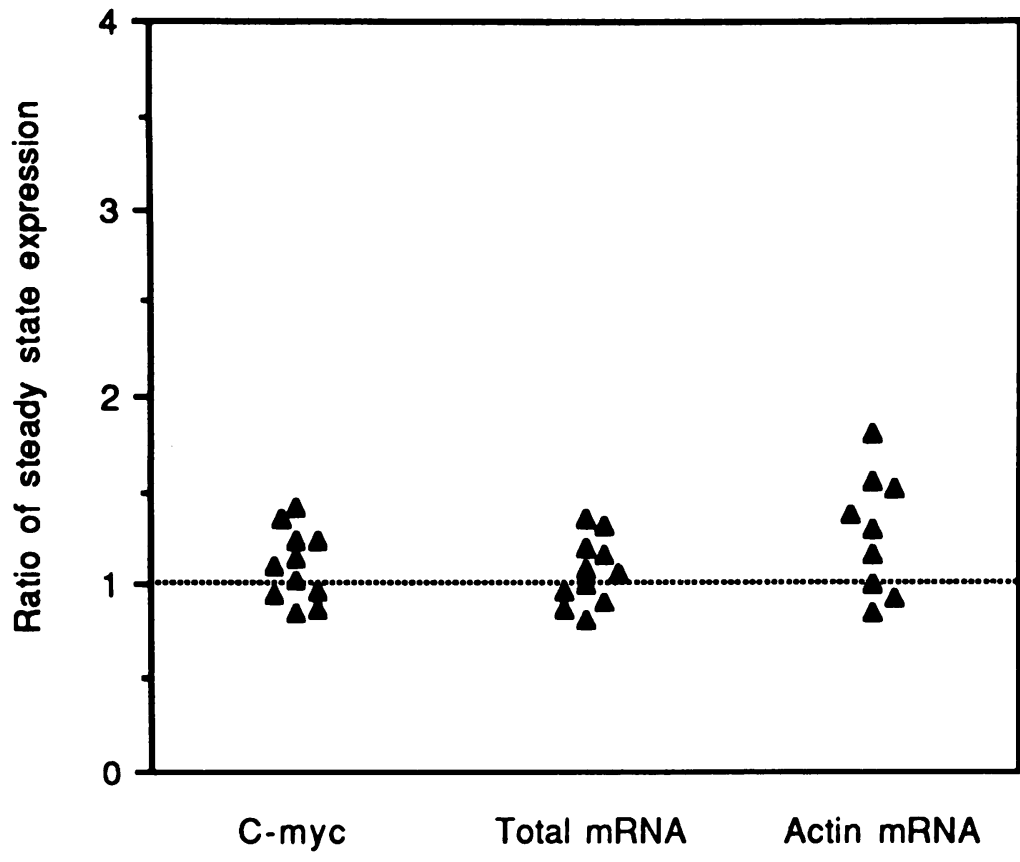

Figure 5: Ratio of expression of c-myc in RNA extracted from colonic biopsies at least $30 \mathrm{~cm}$ apart in patients without macroscopic or histological abnormality and in whom a final diagnosis of irritable bowel syndrome was made. Details as in legend to Figure 3 (in two patients the RNA yields were insufficient to permit measurement of $\beta$-actin $m R N A$ ).

the steady state levels of $c-m y c$ have been seen in peripheral blood leucocytes of patients with systemic autoimmune diseases. ${ }^{3+}$ Our experiments cannot distinguish between the two possible causes of enhanced expression of c-myc mRNA; this would require analysis in cell culture systems.

Our findings are certainly consistent with activation of c-myc as a cause or response of the increased rate of cell proliferation in inflammatory bowel disease. Increased levels of the c-myc protein have previously been detected by immunohistochemistry in the epithelia of patients with ulcerative colitis and Crohn's colitis, ${ }^{21}{ }^{22}$ although there is considerable ambiguity in this method because the cellular localisation of the protein by monoclonal antibodies is dependent on the technique of fixation. ${ }^{2+}$ As similar levels of c-myc expression are seen in (non-dysplastic) ulcerative colitis and colonic Crohn's disease, it is unlikely that this effect is directly related to the pathogenesis of malignancy. We cannot exclude a further increase in c-myc expression occurring during dysplasia, however; this requires further study. Furthermore, infiltration of the inflamed colon by mononuclear cells may in part be responsible for the raised levels of steady state c-myc mRNA; definition of the cell types of the colonic mucosa involved in raised c-myc expression requires further investigation using in situ hybridisation.

In summary, we have applied a method of RNA extraction to colonoscopic biopsies, which overcomes the problems of degradation and reduced yield encountered with surgical specimens. This technique was convenient because active and inactive colonic mucosa from inflammatory bowel disease could be sampled in the same patient. We have shown increased expression of the labile proto-oncogene c-myc in ulcerative and Crohn's colitis; this overcomes the ambiguity and technical difficulties encountered with immunohistochemical studies. Increased expression of c-myc in inflammatory bowel disease is consistent with its activation in cell cycle control as a result of the inflammatory process

We are most grateful to Drs A J Levi, I Forgacs, A B Price, $\mathrm{K}$ Teahon, $\mathrm{P}$ O'Donnell, $\mathrm{R}$ Begent and the staff of the endoscopy units of Northwick Park and Dulwich Hospitals for assistance with this study. Mrs R Greensted provided secretarial assistance. This work was supported by the award of an MRC Training Fellowship to AJSM and grant no SP1850 from the Cancer Research Campaign to $\mathrm{KAC}$ and $\mathrm{ADBM}$ and was presented as an abstract in Gastroenterology 1989; 96: A312.

1 Allan A, Bristol JB, Williamson RCN. Crypt cell production rate in ulcerative proctocolitis: differential increments in rate in ulcerative proctocolitis: differential in
remission and relapse. Gut 1985; 26: 999-1003.

2 Selby WS, Janossy G, Mason DY, Jewell DP. Expression of HLA-DR antigens by colonic epithelium in inflammatory bowel disease. Clin Exp Immunol 1983; 53: 61 14-7.

3 Pallone F, Fais S, Capobianchi MR. HLA-D region antigens on isolated human colonic epithelial cells: enhanced expression in inflammatory bowel disease in in vitro induction by different stimuli. Clin Exp Immunol 1988; 74: 75-9.

4 Weedon DD, Shorter RG, Ilstrup DM, Huizenga KA, Taylor WF. Crohn's disease and cancer. N Engl F Med 1973; 289: 1099-103.

5 Gyde SN, Prior P, Allan RN, Stevens A, Jewell DP, Truelove SC, et al. Colorectal cancer in ulcerative colitis: a cohort study of primary referrals from three centres. Gut 1988; 29: study of $206-17$.

6 Bishop JM. Cellular oncogenes and retroviruses. Ann Rev Biochem 1983; 52: 301-54

7 Kerr LD, Holt JT, Matrisian LM. Growth factors regulate transin gene expression by c-fos-dependent and c-fosindependent pathways. Science $1988 ; 242: 1424-7$

8 Kelly K, Cochran BH, Stiles CD, Leder P. Cell specific regulation of the c-myc gene by lymphocyte mitogens and platelet-derived growth factor. Cell 1983; 35: 603-10.

9 Muller R, Bravo R, Burckhardt J, Curran T. Induction of the c-fos gene and protein by growth factors precedes activation of c-myc. Nature 1984; 311: 716-20.

10 Donner P, Greiser-Wilke I, Moelling K. Nuclear localization and DNA binding of the transforming gene product of avian and DNA binding of the transforming gene product

11 Blackwood EM, Eisenman RM. Max: a helix-loop-helix zipper protein that forms a sequence-specific DNA-binding complex with Myc. Science 1991; 251: 1211-7.

12 Murre C, McCaw PS, Baltimore D. A new DNA binding and dimerisation motif in immunoglobulin enhancer binding, daughterless, myoD and myc proteins. Cell 1989; 56: 777-83.

13 Kelly K, Siebenlist V. The regulation and expression of c-myc in normal and malignant cells. Ann Rev Immunol 1986; 4: 327-38.

14 Rabbitts TH. The c-myc proto-oncogene: involvement in chromosomal abnormalities. In: Bradshaw RA, Prentis S, eds. Oncogenes and growth factors. Amsterdam: Elsevier, 1987: 24-32.

15 Calabretta B, Kaczmarek L, Ming PM, Au F, Ming SC. Expression of c-myc and other cell cycle dependent genes in Expression of c-myc and other cell cycle dependent gen

16 Monnat M, Tardy S, Saraga P, Diggelman H, Costa J. Prognostic implication of expression of the cellular genes $m y \mathcal{c}$, fos, $\mathrm{Ha}$-ras and $\mathrm{Ki}$-ras in colon carcinoma. Int $\mathcal{f}$ Cancer $1987 ; 40: 293-9$

17 Sikora K, Chan S, Evan G, Gabra H, Markham N, Stewart J, et al. C-myc oncogene expression in colorectal cancer. Cancer 1987; 59: 1289-95.

18 Forgacs IC. In: Pounder R, ed. Recent advances in gastroenterology. Molecular genetics in gastroenterology. 1988; 7: 197224.

19 Persson $\mathrm{H}$, Henninghausen L, Taub R, Debrado W, Leder P. Antibodies to human $c-m y c$ oncogene product: evidence of an evolutionarily conserved protein induced during cell proliferation. Science 1984; 225: 687-93.

20 Watson JV, Stewart J, Cox H, Sikora K, Evan GI. Flow cytometric quantitation of the c-mvc oncoprotein in archival cytometric quantitation of the c-myc oncoprotein in archival neoplas.

21 Sundaresan V, Forgacs IC, Wight DGD, Wilson B, Evan GI, Watson JV. Abnormal distribution of the c-myc oncogene product in familial polyposis. $\mathcal{F}$ Clin Pathol 1987; 40: $127+$ 81

22 Ciclitira PJ, Macartney JC, Evan G. Expression of c-mvc in non-malignant and premalignant gastrointestinal disorders. F Pathol 1987; 151: 293-6.

23 Forgacs IC, Sundaresan V, Evan G, Wight DGD, Neale G, Hunter JO, Watson JV. Abnormal expression of e-my oncogene product in dysplasia and neoplasia associated with ulcerative colitis. Gut 1986; 27: A1285.

24 Jones DJ, Ghosh AK, Moore M, Schofield PF. A critical appraisal of the immunohistochemical detection of the c-myc oncogene product in colorectal cancer. Br. F Cancer 1987; 56: oncogen $779-83$.

25 Chirgwin JM, Praybyla AE, MCDonald RJ, Rutter WJ. Isolation of biologically active ribonucleic acid from sources Isolation of biologically active ribonucleic acid from source
enriched in ribonuclease. Biochemistry 1979; 18: 529+-9.

26 Sambrook J, Fritsch EF, Maniatis T. Molecular cloning - a laboratory manual. USA: Cold Spring Harbor Laboratory, 1989. 
27 Feinberg AP, Vogelstein B. A technique for radiolabelling DNA restriction endonuclease fragments to high specific activity. Anal Biochem 1983; 132: 6-13.

28 McMaster GK, Carmichael GG. Analysis of single- and double-stranded nucleic acids on polyacrylamide and agarose gels by using glyoxal and acridine orange. Biochemistry 1977; 74: 4835-7.

29 Pelham HRB, Jackson RJ. An efficient mRNA dependent translation system from reticulocyte lysates. Eur f Biochem 1976; 67: 247-56.

30 Macpherson AJS, Jones-Mortimer MC, Henderson PJF. Identification of the AraE transport protein of Escherichia coli. Biochem f 1982; 196: 296-93.

31 Langley R. Practical statistics. London: Pan Books, 1970.

32 Alberts B, Bray D, Lewis J, Raff M, Roberts K, Watson JD. Molecular biology of the cell. New York: Garland Publishing, 1983

33 Volk BA, Brenner DA, Kagnoff MF. Analysis of RNA transcripts for HLA class II genes in human small intestinal biopsies. Gut 1989; 30: 1220-4

34 Klinman DM, Mushinski JF, Honda M, Ishigatsubo $\mathrm{Y}$, Mountz JD, Raveche ES, et al Oncogene autoimmune and autoimmune and normal peripheral blood mononuclear 